\title{
The Happiness of Smallholder Layer-Chicken Farmers in Rural of East Java, Indonesia
}

\author{
Sutawi $^{\mathrm{a}, *}$, D. Karmiyati ${ }^{\mathrm{b}}$, \& D. Iswatiningsih ${ }^{\mathrm{c}}$ \\ ${ }^{a}$ Faculty of Agriculture and Animal Science, University of Muhammadiyah Malang \\ ${ }^{b}$ Faculty of Psychology, University of Muhammadiyah Malang \\ 'Faculty of Teacher Training and Education, University of Muhammadiyah Malang \\ Jalan Raya Tlogomas 246, Malang 65144, East Java, Indonesia \\ *Corresponding author: sutawi@umm.ac.id \\ (Received 27-02-2020; Revised 14-06-2020; Accepted 16-06-2020)
}

\begin{abstract}
This study was conducted to measure the level of happiness of smallholder layer-chicken farmers in rural East Java based on the subjective well-being conditions. The study was conducted in April 2019 with a survey method in the Malang Regency of East Java Province. Analysis units were $109(20 \%)$ smallholder layer chicken households purposively selected from 543 poultry farmers. Data collection was carried out through interviews using structured questionnaires and assistive tools of scoring on questions related to the dimensions of life satisfaction, affect, and eudaimonia that represent the ladder of life scale on a scale of 0 to 10 . The three dimensions were divided into 19 indicators and used to calculate the Happiness Index. Smallholder layer chicken farmers said that they were "Satisfied" with 8 indicators and "Completely Satisfied" with 2 indicators of Life Satisfaction Dimension, and produced a Life Satisfaction Index of 7.40 (Happy). Farmers said that they were "Satisfied" with the 3 indicators of Affection Dimension and produced the Affection Index of 6.64 (Happy). Farmers said that they were "satisfied" with 6 indicators of Eudaimonia Dimension and produced the Eudaimonia Index of 7.74 (Happy). It can be concluded that the Happiness Index of smallholder layer chicken farmers in rural areas of East Java Province was 7.28 and classified as "Happy".
\end{abstract}

Keywords: affection; chicken farmers, eudaimonia; happiness index; life satisfaction

\section{INTRODUCTION}

The prospect of layer chicken in Indonesia is considered impressive in terms of population, production, and consumption. The population of layer chicken in 2016 amounted to 161.35 million birds with egg production of 1.49 million tons and eggs consumption of 6.30 $\mathrm{kg} /$ capita/year, increasing respectively to 166.72 million birds, 1.53 million tons, and $6.53 \mathrm{~kg} /$ capita/year in 2017 . The consumption for egg and other livestock products will be driven by economic progress, population growth, urbanization, and changing consumer preferences (Agus \& Widi, 2018; Smith et al., 2018) as well as their knowledge about the importance of animal protein consumption (Mallu et al., 2018) and improvement of living standard (Rudatin, 2016). The prospect of layer chicken farming can be viewed from the indicators of benefit and Farmers' Terms of Trade (FTT). The farming can produce benefits around IDR 1,000-3,000/kg of eggs (Ngantung et al., 2019; Widiati et al., 2017). FTT in the livestock sub-sector of 2017 reached 106.95, increasing to 107.34 in 2018. FTT is a proxy indicator of farmer welfare. FTT over 100 shows that the farmers are prosperous (Rachmat, 2013).
The welfare level is not only measured by monetary or material indicators, but also by subjective well-being or happiness indicators (Tolentino \& Dullas, 2015). Happiness is conceived as the degree to which an individual judges the overall quality of his life as favorable (Veenhoven, 2012). Happiness is interpreted as something that is felt from the achievement of pursuing and fulfilling effort to one's potential and purpose of life (Forgeard et al., 2011). It can also be interpreted as life evaluation of the whole life aspects by concerning on feeling (affection) including the emotional experience (OECD, 2013) and eudaimonia (flourishing/eudaimonic) related to a person's psychological functions (Deci \& Ryan, 2008; Dodge et al., 2012; Huppert, 2009).

The happiness indicators are arranged to describe the conditions of material well-being and subjective well-being related to some life aspects that are essential and meaningful for the population. A relatively broad definition of subjective well-being is good mental states, including all of the various evaluations, positive and negative, that people make of their lives and the affective reactions of people to their experiences (OECD, 2013). This definition of subjective well-being hence encompasses three elements: (1) Life evaluation (a 
reflective assessment on a person's life or some specific aspect of it; (2) Affection (a person's feelings or emotional states, typically measured concerning a particular point in time; and (3) Eudaimonia (a sense of meaning and purpose in life, or good psychological functioning). The indicators of happiness give a general view about the satisfaction level that is subjectively valued by the population-related on the evaluation result of objective/ life factual conditions in life satisfaction, feeling, and the meaning of life. By expressing their feelings on single or multiple scales, individuals tell how they view their life as a whole, or some particular domain of life, as favorable.

As many as $95 \%$ of layer chicken in East Java are classified as smallholder livestock businesses. Small farmers are often referred to as less happy families in line with problems faced, both social, technical, and economical. Research on the welfare of layer chicken farmers generally examines social and economic aspects, while psychological aspects are still scarce. This study has the purpose of measuring the level of happiness of smallholder layer chicken farmers in rural East Java based on the subjective well-being conditions that include the dimensions of life satisfaction, affect, and eudaimonia. This study adopted a BPS (Statistics Indonesia) survey on population happiness, which was applied to layer chicken farmers.

\section{METHODS}

\section{Farmer Respondent}

The study was conducted in April 2019 using a survey method in Malang Regency, one of 33 regencies that contribute 5.91 million birds (12.61\%) of 46.9 million birds of layer chicken population in East Java Province of Indonesia. The design of this research was a quantitative research technique by using an interview questionnaire to obtain data at the household level. Analysis units were 109 (20\%) smallholder layer chicken households purposively selected from 543 poultry farmers with the ownership of fewer than 5,000 birds and have managed their livestock business for more than five years.

The data collection was performed through interviews by using structured questionnaires and assistive devices of scoring (rating scale) to questions related to life satisfaction, affect, and eudaimonia, which represented the ladder of life scale on the scale of 0 to 10 . Score 0 showed the answers of respondents about their most dissatisfaction/the lowest, while score 10 represented the condition of respondents about the most satisfaction/the highest. The satisfaction level of farmers was divided into five categories: (1) 0.00-2.00, "Completely Dissatisfied"; (2) 2.01-4.00, "Dissatisfied"; (3) 4.01-6.00, "Moderately Satisfied"; (4) 6.01-8.00, "Satisfied"; and (5) 8.01-10.00, "Completely Satisfied".

\section{Happiness Indicators}

The Happiness Index is the composite index composed of 3 dimensions, namely: Life Satisfaction
Dimension, Affection Dimension, and Eudaimonia (Meaning of Life) Dimension (OECD, 2013). The Life Satisfaction Dimension was divided into 2 sub-dimensions, namely Personal Life Satisfaction Sub-dimension and Social Life Satisfaction Sub-dimension. The Personal Life Satisfaction Sub-dimension was measured by using 5 indicators: Education and Skills, Main Jobs, Household Income, Health, and Housing, while the Social Life Satisfaction Sub-dimension was measured by using 5 indicators: Family Harmony, Work-Life Balance, Social Relationship, Environmental Condition, and Security. The Affection Dimension was measured by using 3 indicators: Positive Emotions, Negative Emotion, and Depressed. Eudaimonia Dimension consisted of 6 indicators, namely Self-Acceptance, Purpose in Life, Positive Relation with Others, Personal Growth, Environmental Mastery, and Autonomy. Overall, the Happiness Index was measured by 19 indicators.

Each dimension, sub-dimension, and indicator had different contributions to arrange the Happiness Index. Those contributions could be viewed from the weight of each dimension/indicator as well as the value of each constituent indicator. The value of each indicator was the answers of respondents concerning their satisfaction of 19 indicators of Happiness Index, while the weights of each dimension, sub-dimension, and the indicator were calculated based on the data distribution. Determinations of dimensions, sub-dimensions, indicators, the weights, and Happiness Index formula were guided by a Survey of Happiness Measurement 2017 or "Survei Pengukuran Tingkat Kebahagiaan 2017" (Statistics Indonesia, 2017) (Table 1).

\section{Happiness Index}

Happiness Index is a weighted composite index of 3 constituent dimensions, thus before calculating the Happiness Index, the index of each dimension must first be calculated. The formula used in calculating the dimensions of the components of happiness is as follows:

$\mathrm{LSI}=\left\{(\mathrm{w} 4 * \mathrm{PLSI})+\left(\mathrm{w} 5^{*} \mathrm{SLSI}\right)\right\} /(\mathrm{w} 4+\mathrm{w} 5)$

PLSI $=\sum\left(w i^{*} x i\right) / \sum w i$

SLSI $=\sum\left(w i^{*} x i\right) / \sum w i$

$\mathrm{AI}=\sum\left(\mathrm{wi}^{*} \mathrm{xi}\right) / \sum \mathrm{wi}$

$\mathrm{EI}=\sum\left(w i^{*} x i\right) / \sum w i$

Afterward, the Happiness Index was calculated by this formula:

$$
\mathrm{HI}=\left\{\left(\mathrm{w} 1^{*} \mathrm{LSI}\right)+\left(\mathrm{w} 2^{*} \mathrm{AI}\right)+\left(\mathrm{w} 3^{*} \mathrm{EI}\right)\right\} /(\mathrm{w} 1+\mathrm{w} 2+\mathrm{w} 3)
$$

Where LSI is Life Satisfaction Index; PLSI is Personal Life Satisfaction Index; SLSI is Social Life Satisfaction Index; AI is Affection Index; EI is Eudaimonia Index; HI is Happiness Index; $x i$ is a score of the $i$ indicator; $w i$ is the weight of $i$ indicator, where $i=1, \ldots, 5$ are for Personal Life Satisfaction indicators, $i=6, \ldots, 10$ are for Social Life Satisfaction indicators, $i=11,12,13$ are for Affection indicators, $i=14, \ldots, 19$ are for Eudaimonia indicators; and $w 1, w 2, w 3, w 4, w 5$ are weight of Life Satisfaction Dimension, Affection Dimension, Eudaimonia Dimension, Personal Life Satisfaction Sub-dimension, and Social Life Satisfaction Dimension, respectively. 
Table 1. Determination of dimensions, sub-dimensions, indicators, and indicator weights

\begin{tabular}{|c|c|c|c|c|c|}
\hline \multirow[b]{2}{*}{ Dimensions } & \multirow[b]{2}{*}{ Sub-dimensions } & \multirow[b]{2}{*}{ Indicators } & \multirow[b]{2}{*}{$\begin{array}{l}\text { The weights } \\
\text { (wi) }\end{array}$} & \multicolumn{2}{|c|}{ Indicators scores (xi) } \\
\hline & & & & $\begin{array}{c}\text { 1-2-3-4-5 } \\
\text { Unsatisfied }\end{array}$ & $\begin{array}{c}\text { 6-7-8-9-10 } \\
\text { Satisfied }\end{array}$ \\
\hline \multirow{10}{*}{$\begin{array}{l}\text { Life Satisfaction } \\
(\mathrm{w} 1=34.80)\end{array}$} & \multirow{5}{*}{$\begin{array}{l}\text { Personal Life } \\
\text { Satisfaction } \\
(\mathrm{w} 4=50.00)\end{array}$} & 1. Education and Skills & 18.34 & & \\
\hline & & 2. Main Jobs & 21.67 & & \\
\hline & & 3. Household Income & 22.81 & & \\
\hline & & 4. Health & 17.04 & & \\
\hline & & 5. Housing & 20.14 & & \\
\hline & \multirow{5}{*}{$\begin{array}{l}\text { Social Life Satisfaction } \\
(w 5=50.00)\end{array}$} & 6. Family Harmony & 19.41 & & \\
\hline & & 7. Work and Life Balance & 18.93 & & \\
\hline & & 8. Social Connectedness & 22.13 & & \\
\hline & & 9. Environmental Condition & 20.64 & & \\
\hline & & 10. Security & 18.89 & & \\
\hline \multirow[t]{3}{*}{ Affection (w2=31.18) } & & 11. Positive Emotion & 25.86 & & \\
\hline & & 12. Negative Emotion & 36.80 & & \\
\hline & & 13. Depressed & 37.34 & & \\
\hline \multirow[t]{6}{*}{ Eudaimonia (w3=34.02) } & & 14. Autonomy & 16.56 & & \\
\hline & & 15. Environmental Mastery & 18.44 & & \\
\hline & & 16. Personal Growth & 15.27 & & \\
\hline & & 17. Positive Relation with Others & 15.48 & & \\
\hline & & 18. Purpose in Life & 17.48 & & \\
\hline & & 19. Self-Acceptance & 16.78 & & \\
\hline
\end{tabular}

Source: Statistics Indonesia (2017)

Determination of the weight $(w)$ of dimensions, subdimensions, and indicators was guided by a Survey of Happiness Measurement 2017.

Based on the value of the Happiness Index, the happiness level of farmers was classified into five categories: (1) 0.00-2.00, "Completely Unhappy"; (2) 2.01-4.00, "Unhappy"; (3) 4.01-6.00, "Moderately Happy"; (4) 6.01-8.00, "Happy"; and (5) 8.01-10.00, "Completely Happy".

\section{RESULTS}

\section{Indicators of Happiness Index}

The scores of 19 indicators compiling the Happiness Index of smallholder layer chicken farmers are presented in Figure 1 and the calculation of the Happiness Index in Table 2. On the Life Satisfaction Dimension, the highest-score indicator on Personal Life Satisfaction Sub-dimension was Housing (7.53), and on Social Life Satisfaction Sub-dimension was Security (8.10), while the lowest scores on those sub-dimensions were Education and Skills (6.73) and Family Harmony (6.86). On Affection Dimension, the highest-score indicator was Positive Emotion (7.70), and the lowest was Depressed (6.20). On the Eudaimonia Dimension, the highest-score indicator was Purpose in Life (7.97) and the lowest was Positive Relationship with Others (7.43). The scale of farmers' satisfaction scores for 17 indicators of happiness was classified as "Satisfied" and 2 indicators of "Completely Satisfied".

\section{DISCUSSION}

\section{Life Satisfaction Dimension}

The most widely used type of measures to assesses well-being in many large-scale international surveys is measures of life satisfaction. Life satisfaction assesses a person's quality of life according to his chosen criteria. Life satisfaction judgments, therefore, depend on the standards individuals have set for themselves (Forgeard et al., 2011). Life Satisfaction is an evaluation of an objective condition from 10 essential life domains experienced by the population (OECD, 2013). Layer chicken farmers said that they were "Satisfied" with eight indicators and "Completely Satisfied" with two indicators of Life Satisfaction Dimension. Satisfaction figures for 10 Life Satisfaction indicators produced a Life Satisfaction Index (LSI) of 7.40 (Happy), consisting of a Personal Life Satisfaction Index (PLSI) of 7.22 (Happy) and Social Life Satisfaction Index (SLSI) of 7.59 (Happy). Those indexes show that layer chicken farmers are "Happy" with the objective conditions of their life domain.

Farmers' satisfaction with the Education and Skills indicators of 6.73 (Satisfied) was the lowest. The result showed that the majority of the farmers had lower education. Some $28(26.03 \%)$ farmers had elementary school education, and $72(66.67 \%)$ farmers were in junior high schools, the remaining $4(3.7 \%)$ farmers were in senior high schools, and 4 (3.7\%) farmers were in colleges/universities. Low education level influences the ability to interpret and apply technology and innovation related to the development of their business (Kurniati, 2014). Higher education opens up greater opportunities to 


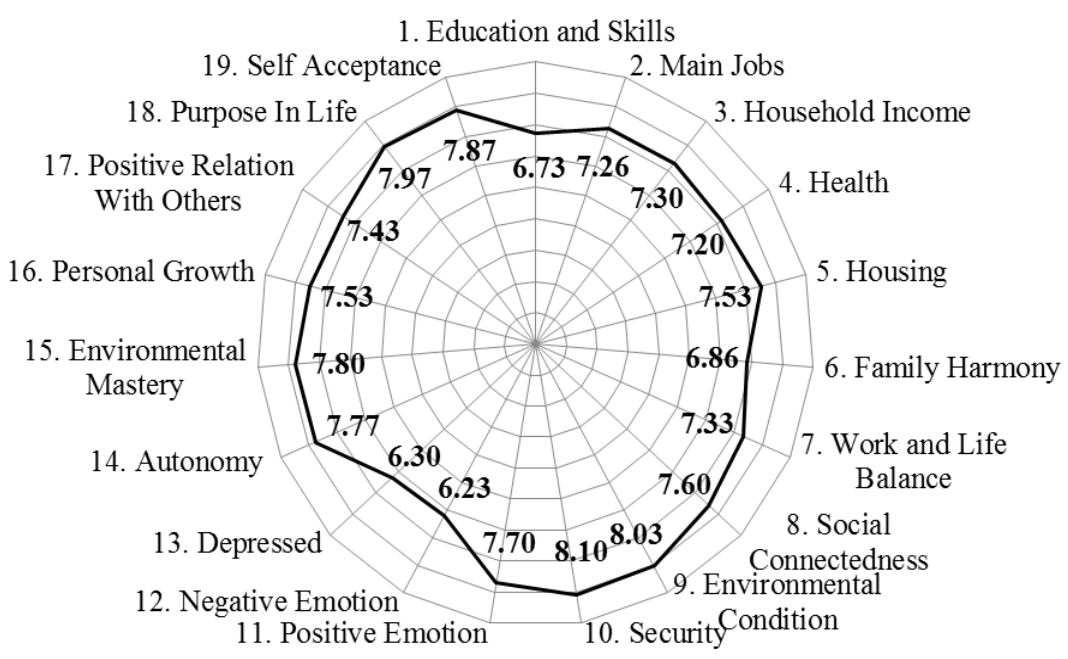

Figure 1. The scores of 19 indicators compiling the Happiness Index of smallholder layer chicken farmers

Table 2. The calculation of Happiness Index

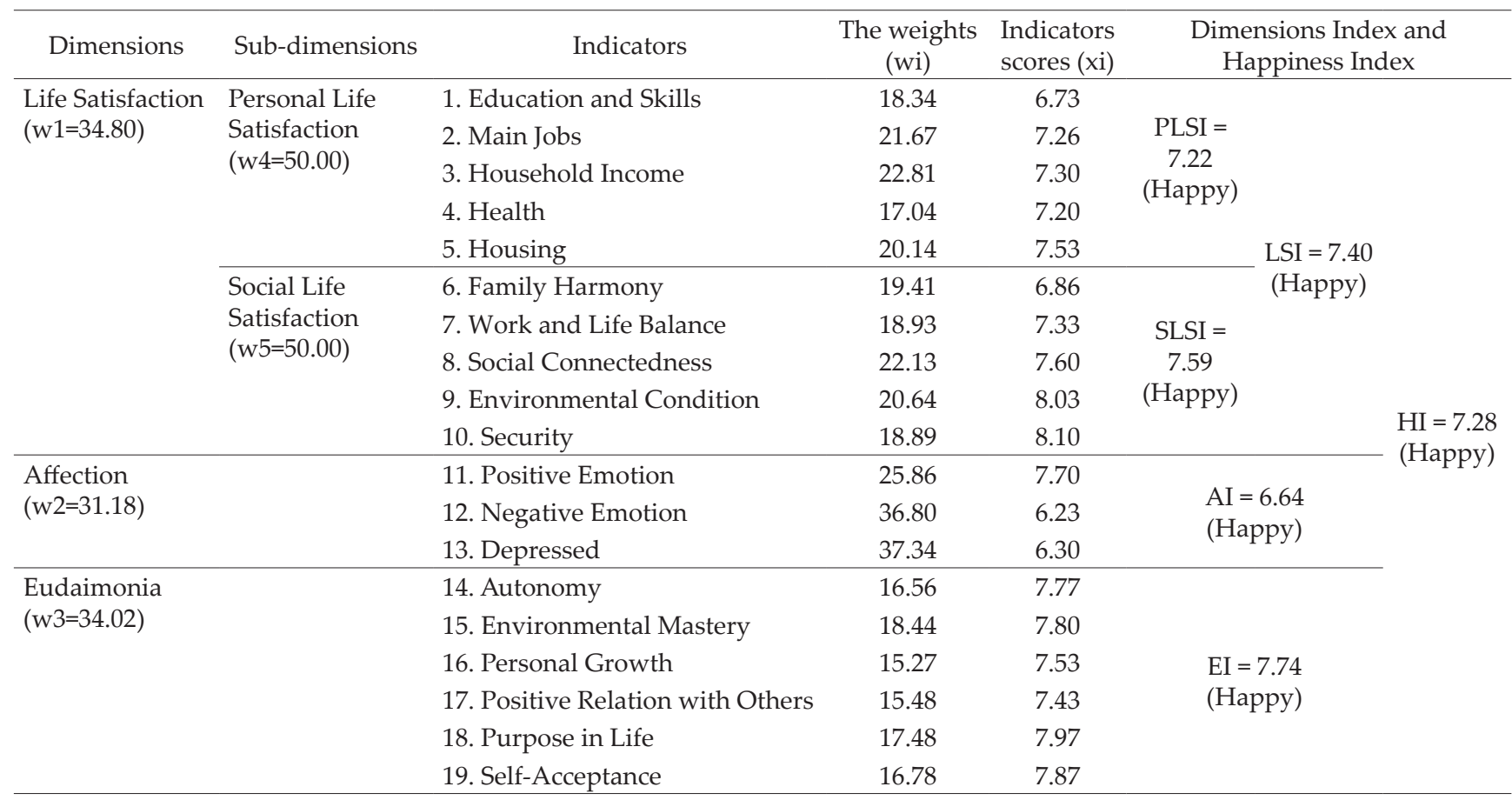

Note: LSI= Life Satisfaction Index; PLSI= Personal Life Satisfaction Index; SLSI=Social Life Satisfaction Index; AI=Affection Index; EI=Eudaimonia Index; HI=Happiness Index.

establish a relationship or a wider network (Chen, 2012). Education and skills are linked to reductions in household poverty and generally, higher indicators of household well-being (McNair et al., 2015). The direct effect of education on happiness is to improve self-confidence and pride and the pleasure of gaining knowledge, and the indirect effect can be seen from the effect of education on higher employment opportunities, better jobs, higher salaries, and better health (Cuñado \& Gracia, 2012). One way to improve farmers' knowledge and skills is agricultural extension education. Agricultural extension education is a very important factor in the farming process as it provides all the information about the latest innovations, advanced farming methods, and all the government policies related to agriculture (Chen et al., 2017). Agricultural extension knowledge significantly and positively improving perceived farming performance (Suksod et al., 2019).

Farmers' satisfaction with the Main Jobs indicator was in the score of 7.26 (Satisfied). Farmers, on average, raised 3,760 birds with an average income of IDR 5.280 million per month. The income is equal to broiler farmers under contract system on scale size of 3,000 chickens of IDR 3.774-7.300 million per period (Harianto et al., 2019). The income of farmers is higher than those of rice farmers of IDR 715,000-1,500,000 per month (Listiani et 
al., 2019; Primasari \& Puspitawati, 2016). Household income has a positive influence on happiness (Bartolini \& Bilancini, 2010; Deaton, 2008; Dedehouanou et al., 2013). The higher the income, the higher the level of happiness (Rahayu, 2016; Yakubu \& Aidoo, 2015). Income plays an essential role in welfare in developing countries (Lelkes, 2006) and developed countries (Shields \& Price, 2005).

Farmers' satisfaction with the Health indicator was 7.20 (Satisfied). The government of Malang Regency provides healthcare facilities and health workers, which spread out throughout districts. The available healthcare units in Malang Regency are 24 units of hospitals, 12 units of maternity hospitals, 39 units of community health centers, 2,838 units of integrated service posts, 44 units of clinics, and 390 units of village maternity huts. Those healthcare facilities are supported by medical workers and paramedic of 317 doctors and 245 specialists, 2,533 nurses, 890 midwives, 262 pharmacy staff, 115 nutritionists, and 263 medical technicians. The number of healthcare units has positive and significant effects on public welfare (Latuconsina, 2017). Good health, on the one hand, will increase happiness, and on the other hand, happy people will have higher health (Rahayu, 2016).

Farmers' satisfaction with Housing was 7.53 (Satisfied). Each farmer lives in a house of 100-150 $\mathrm{m}^{2}$ with 3-4 bedrooms, a living room, a family room, a kitchen, and a bathroom. The houses of farmers have facilities of electricity, drinking water, televisions, fuel gas for cooking, and mobile phone for communication. The houses also have front yards for about $100-200 \mathrm{~m}^{2}$ that are used to plant vegetables and fruit. The conditions of the house and home facilities supporting the comfort of life are very important, not only for fulfilling the basic needs as a decent place to live but also for fulfilling a sense of security from the shortcomings and the creation of comfort in life. Adequate housing is a fundamental human right because housing quality affects farmworker physical and mental health (Arcury et al., 2015).

Farmers' satisfaction with the Family Harmony indicator was 6.86 (Satisfied). A harmonious family is contributed by 4 components: communication, mutual respect, lack of conflict, and having time for family (Lam et al., 2012). Harmony includes their harmony with family members (family life that tends to be good, peaceful, and away from contention), firmness (united in living everyday life and facing all problems), trust in the family (believe that family members will do positive actions), and sufficient time for family activities (watching/gathering/having family time, recreation/traveling to other cities with family, and so on). The harmony in family life is very meaningful for an individual because a family is a reason and a motivation for a person to live his/her life well. Family harmony ought to be kept up so that the family can perform their obligations and capacities properly and balanced (Sari \& Puspitawati, 2017).

Farmers' satisfaction with Work-Life Balance was 7.33 (Satisfied). Workers in layer chicken farming are from farmer families that consist of a father as the leader of the family, a wife, and children. They allocate time for about 3-4 hours per day, together or alternately, to manage their chicken farming business, such as giv- ing feed and drinks, cleaning the cage, giving chicken vaccination, or taking and selling the eggs. Therefore, farmers have enough time to do some activities in social, religion, sport, or recreation with the family, siblings, or neighbors. The ability of someone to balance his time for working and relaxing activities or having fun by himself or with other people will make him keep healthy, unstressed, and productive. Work-Life Balance has a positive and significant impact on happiness (Bataineh, 2019).

Farmers' satisfaction with Social Connectedness was 7.60 (Satisfied). Good social relationship with neighbors and community is the basic needs of farmers as a social creature. It is related to the harmony or trust between residents and the availability of time and opportunities to socialize with the surrounding community. The social relationship has a significant role in happiness in Indonesia (Rahayu, 2016). The formulation of farmers' organizations is an important tool of assuring smallholder farmers to improve households' well-being (Msuta \& Urassa, 2015). Farming activities do not only give material happiness of cultivating production and income, but also give non-material happiness in the form of gathering with families, neighbors, and give job opportunities for their surrounding community (Permana \& Fauzy, 2016). Social support, the belief that one is cared for, loved, esteemed, and valued, has been recognized as one of the most (if not the most) influential determinants of well-being for people of all ages and cultures (Reis \& Gable, 2003).

Farmers' satisfaction with the Environmental Condition indicator was 8.03 (Completely Satisfied). Living environmental quality in Malang Regency during the year of 2017 was quantitatively measured by the indicator of Environmental Quality Index (EQI) on the amount of 68.5 (Pretty Good), better than EQI of East Java Province, i.e., 57.46 (Not Good) and Indonesian EQI, i.e., 66.64 (Pretty Good). The living environmental quality is interpreted as an environmental condition that can give optimal support to human survival in a region (Suryani, 2018). The quality of the environment is characterized by an atmosphere that makes people feel comfortable living in their places. The quality of the environment in which a person lives is very influential in health and the freedom to carry out various daily activities. Environmental quality is believed to have a direct impact on their health and well-being. An unspoiled environment provides comfort for someone to move and allows people to recover from stress due to the routine of life.

Farmers' satisfaction with Security was 8.10 (Completely Satisfied). Activities to maintain the security and order of rural communities in Malang Regency is called Environmental Security System or "Sistem Keamanan Lingkungan (Siskamling)". Siskamling is a joint effort of all citizens in improving the security and public order system by prioritizing efforts to prevent and ward off forms of threats and disturbances by public security and order. Citizen participation in the implementation of Siskamling is carried out routinely with the distribution of schedules by a community leader. Security condition in the neighborhood and any 
environment affects the creation of a sense of security for someone who is also closely related to the comfort of life and happiness. The safer the greater the comfort, so that the greater the happiness of the community (Rahayu, 2016).

\section{Affection Dimension}

Affection is an evaluation measurement/experience related to the feeling of the whole life that describes the levels of two hedonism measurements [positive-negative affects] (OECD, 2013). Smallholder chicken farmers said that they were "Satisfied" with the three indicators of Affection Dimension, namely: Positive Emotion (7.70), Depressed (6.30), and Negative Emotion (6.23). The three indicators produced the Affection Index (AI) of 6.64 (Happy).

Farmers' satisfaction with indicators of Positive Emotion was 7.70 (Satisfied). Farmers are happy to run their businesses as jobs because of the benefits that are owned by chicken farms. Layer chicken production has advantages including: has become one of the business fields that are accepted and developed by the community; production technology has been mastered; support agriculture businesses; become a mainstay commodity of the community in meeting nutritional needs; capital turnover that is relatively fast; and the ability to accommodate a large enough workforce (Zaheer, 2015; Mbuza et al., 2016). When it is viewed by SWOT (strengths, weaknesses, opportunities, and threats) analysis, the business of layer chicken farming has good strengths and opportunities. The strengths of this business are: production facilities for the breed, feed, medicine, and equipment supplies; technical production has been mastered, easy eggs marketing; while the opportunities include: population growth, economic growth, and better public nutrition awareness (Kurniawan et al., 2011; Kurniawan et al., 2013; Pelafu et al., 2018).

Farmers' satisfaction with indicators of Negative Emotion was 6.23 (Satisfied) and Depressed was 6.30 (Satisfied). The business of layer chicken farming has low-risk production and egg prices (Ulfa et al., 2014). The biggest production risk is if there is an outbreak of avian influenza (AI), as it once hit Asia in 2004-2006 and made chicken production in Indonesia fell to $60 \%$ (Ilham \& Yusdja, 2010). Small-scale poultry business is very vulnerable to the transmission of the disease that is harmful to livestock and human life because the economic capacity and knowledge of implementing biosecurity are very limited (Martindah et al., 2014). Fluctuations in the price of eggs and feed are risks that often are faced by layer chicken farmers. Beside of being caused by fundamental factors such as the increase in feed prices and DOC as well as the structure of the poultry market tends to be oligopolistic in the input market and oligopsony in the output market, the increase in egg prices is caused by reduced egg production due to disease attacks on chickens which causes production to decline sharply (Ilham \& Saptana, 2019; Nuryati \& Nur, 2012).

\section{Eudaimonia Dimension}

The Eudaimonia (Meaning of Life) is a concept of good psychological functioning or flourishing in the positive psychology field that describes the meaningfulness of life that exceeds one's self. This dimension contains six indicators known as Psychological Well-Being (OECD, 2013): (1) autonomy, (2) environmental mastery, (3) personal growth, (4) positive relations with others, (5) purpose in life, and (6) self-acceptance. Smallholder layer chicken farmers said that they were "satisfied" with six indicators of Eudaimonia Dimension. Those indicators produced the Eudaimonia Index of 7.74 (Happy).

Farmers' satisfaction with the Autonomy indicator was 7.77 (Satisfied). Autonomy is a key indicator of happiness for farmers despite lower incomes or longer work hours. Farmers describe autonomy as a particular lifestyle connected to farming, the equivalent of being one's own boss, and the constraints that limit their farming operations (Stock \& Forney, 2014). Farmers are agri-business entrepreneurs who manage their own layer chicken business. Farmers require entrepreneurship skills in responding to technology development. They have to adopt the innovation in their businesses to scale up their welfare (Pambudy, 2018). They have the freedom to access technical information, capital, market, and other information as needed, to increase productivity, business efficiency, and income. Their independence is known from the indicators of awareness and desire to change, the ability to increase the capacity to gain access to technology and capital, the ability to face obstacles, and the ability to cooperate and solidarity with farmers (Rahmawati et al., 2016).

Farmers' satisfaction with the indicator of Environmental Mastery was 7.80 (Satisfied). Environmental Mastery is the ability to develop skills that are suitable for their activities or work. Farmers have experience with managing their farms for 5-20 years. They have become proficient in managing their livestock businesses, in terms of technical, economic, social, and political aspects. Local government provides agricultural advisors whose role is to assist farmers in improving their potential (empowering) they have and developing them (enabling) so that they can be more creative and independent (Rahmawati et al., 2016). Extension activities are one of the government's efforts that have an important role in improving the knowledge, skills, and attitudes of farmers. Agricultural advisors play a significant role in the transfer of knowledge and good farming practices (Ofuoku, 2012; Dahlan et al., 2014). The good extension has succeeded in improving the socio-economic well-being (happiness) of the farmers and farming community in general (Kamaruddin et al., 2013; Maoba, 2016).

Farmers' satisfaction with Personal Growth was 7.53 (Satisfied). The personal growth is related to the desire to develop the potential from time-to-time, which is also directly proportional to the happiness that someone will feel. Farmers develop their business scale according to the profits and capital they have. Farmers with a business scale of fewer than 2,500 birds generally do busi- 
ness less than 5 years as a novice farmer. Farmers with a business scale of 2,500-5,000 have been doing business for 6-10 years, and a business scale of more than 5,000 is more than 10 years. Based on NPV, Net B/C, and IRR indicators, laying hens raising businesses to meet the eligibility criteria (Ulfa et al., 2014; Widiati et al., 2017). Small-scale laying poultry business (less than 5,000 birds) requires an investment of IDR 67,000 per bird and produces NPV IDR 37 million (positive), B/C ratio 1.02 (more than one), and IRR $20.58 \%$ (more than social discount rate).

Farmers' satisfaction with Positive Relation with Other indicators was 7.43 (Satisfied). Positive relationships with others related to the relationship of a person with someone else. A positive relationship with other people is an interaction, not just a passive relationship, to develop more productive and satisfying results. Respondents who have a positive relationship create a sense of caring, empathy, compassion, and mutual trust that makes the respondent's life useful to others. A positive relationship that appeared in a social environment is the major factor and the source of one's happiness (Modiri, 2019). In rural society, a positive relationship among the farmers and the stakeholders as a part of social capital is very important and very helpful for the citizens and the development of the agricultural itself (Wibisono \& Darwanto, 2016).

Farmers' satisfaction with the indicators of Purpose in Life was 7.97 (Satisfy). The Purpose of Life associated with life goals and ideas about the meaningful future. Breeders manage their businesses as the major business to earn enough income to live properly. Employment in a laying chicken farm is a prospective job because the price and demand for eggs tend to increase every year. During the 2014-2018 period, the price of broiler eggs at the producer and consumer levels continued to increase to IDR 19,724 per $\mathrm{kg}$ in 2018 compared to previous years with a range of IDR 15,131-17,479 per $\mathrm{kg}$ (Ilham \& Saptana, 2019). The most important factors driving egg demand are population and growth, income levels, the phenomenon of urbanization and market segmentation, and consumer preferences.

Farmers' satisfaction with the indicator of SelfAcceptance was 7.87 (Satisfied). Farmers get the benefits of livestock farming for families, communities, and countries. Laying chicken farming is a part of agricultural development that aims to provide animal food in the form of eggs and highly nutritious chicken meat, as a source of family income, expand employment opportunities in rural areas, reduce food imports, and increase foreign exchange (Ulfa et al., 2014; Widiati et al., 2017). The smallholder livestock business also supports government programs in reducing poverty, providing employment, and a source of income for some rural communities (Kurniawan et al., 2013).

\section{Happiness Index}

Based on the 19 scores of happiness indicators, the magnitude of the index of each dimension of the Happiness Index, were (1) Index of Life Satisfaction of 7.40 (Happy), consisting of Personal Life Satisfaction
Index of 7.22 (Happy) and Social Life Satisfaction Index of 7.59 (Happy); (2) Affection Index of 6.64 (Happy); and (3) Eudaimonia Index of 7.74 (Happy). Based on these three dimensions, the amount of Happiness Index of laying hens farmers in the rural East Java Province during the year 2019 was 7.28 and classified as "Happy". The Happiness Index of laying hens farmers was greater than the Happiness Index of Indonesian People of 7.07 in 2018, the Happiness Index of Indonesian People in rural areas of 6.96, and the Happiness Index of East Java Province's People of 7.08 (Statistics Indonesia, 2017). The highest Happiness Index was reached by North Maluku Province's People of 7.57. In North Maluku, the agricultural sector contributed the most to the GDRP (Gross Domestic Regional Product) of $23.95 \%$ and $45.73 \%$ of the population work in the agricultural sector. This fact shows that the population who work in the agricultural sector, including farmers, forestry, and fisheries, is classified as happy.

This finding is consistent with results from several other countries. In Malaysia, most farmers would be living below the absolute poverty line, but they are happy and proud to be a farmer (Kamaruddin et al., 2013). About $99.0 \%$ of 400 Ohio farmers reported satisfaction with their overall quality of life (Windon et al., 2014). UK farmers are among the most satisfied workers in the country. A new happiness index found that people working in the countryside - farming, fisheries, and forestry - were happiest with their lot (Khaleeli, 2012). A survey conducted by Bahrmann (2015) ranked farmers as the second happiest profession. Livestock is an important source of rural prosperity and in general are important for the people's wealth, health, enjoyment, amusement, and general happiness in India (Mandal et al., 2006). In Ghana, seven out of ten less prosperous subsistence farmers were happy with their lives (Yakubu \& Aidoo, 2015). The happiness of a nation is like a tree, agriculture is its roots, commerce and industry are its branches and leaves. If the root is removed, the branches will die and the leaves drop off (Adebisi et al., 2019; Bamiro et al., 2013; Odunlami et al., 2016). The chores on a farm are many and the monetary rewards often limited, but many farmers do not think of their occupation solely in terms of cash. This fact shows that other dimensions determine the level of their happiness, other than financial terms.

\section{CONCLUSION}

The Happiness Index of smallholder layer chicken farmers in rural areas of East Java Province was 7.28 and classified as "Happy". Efforts to increase the happiness of farmers can be done by the government and stakeholders by increasing the knowledge and skills of farmers through agricultural extension education and maintaining the stability of egg prices.

\section{CONFLICT OF INTEREST}

The authors confirm that there is no conflict of interest with any financial, personal, or other relationships with other people or organizations related to this paper. 


\section{ACKNOWLEDGEMENT}

The research for this paper was funded by the University of Muhammadiyah Malang through Research Grant 2019.

\section{REFERENCES}

Adebisi, L. O., O. Jimoh, J. Asuquo, K. K. Osasona, \& E. O. Ojediran. 2019. Effect of contract farming on poultry farming. Agro-Science: J. Trop. Agric. Food, Environ. Ext. 18:45-49. https://doi.org/10.4314/as.v18i1.7

Agus, A. \& T. S. M. Widi. 2018. Current situation and future prospects for beef cattle production in Indonesia - A review. Asian-Australas. J. Anim. Sci. 31:976-983. https://doi. org/10.5713/ajas.18.0233

Arcury, T.A., I. J. Jacobs, \& V. Ruiz. 2015. Farmworker housing quality and health. New Solutions: J. Environ. Occup. Health Policy. 25:256-262. https://doi. org/10.1177/1048291115604426

Bahrmann, S. 2015. Why care about small-scale farming? Because of soil, sex, success and happiness. Future of Food: J. Food Agric. Soc. 2:8691.

Bamiro, O. M., A. O. Otunaiya, \& I. Adejumo. 2013. Profit efficiency in poultry production in Peri-Urban Lagos, Nigeria. Int. J. Appl. Agric. Apic. Res. 9:120-130.

Bartolini, S. \& E. Bilancini. 2010. If not only GDP, what else? Using relational goods to predict the trends of subjective well- being. Int. Rev. Econ. 57:199-213. https://doi. org/10.1007/s12232-010-0098-1

Bataineh, K. A. 2019. Impact of work-life balance, happiness at work, on employee performance. Int. Bus. Res. 12:99-112. https://doi.org/10.5539/ibr.v12n2p99

Chen, Q., Z. Wen, Y. Kong, J. Niu, \& K. T. Hau. 2017. Influence of leaders' psychological capital on their followers: multilevel mediation effect of organizational identification. Frontiers in Psychology. 8:1-12. https://doi.org/10.3389/ fpsyg.2017.01776

Chen, W. 2012. How Education enhances happiness: Comparison of mediating factors in four East Asian Countries. Soc. Indic. Res. 106:117-131. https://doi. org/10.1007/s11205-011-9798-5

Cuñado, J. \& F. P. Gracia. 2012. Does education affect happiness? Evidence for Spain. Soc. Indic. Res. 108:185-196. https://doi.org/10.1007/s11205-011-9874-x

Dahlan, S. S., P. Mappigau, \& S. Khaerani. 2014. Human capital and best practice management adoption of among small scale maize farmer in Bantaeng District, Indonesia. J. Mark. Manag. 2:81-96. https://doi.org/10.15640/jmm

Deaton, A. 2008. Income, health, and well-being around the world: Evidence from the Gallup World Poll. J. Econ. Perspec. 22:53-72. https://doi.org/10.1257/jep.22.2.53

Deci, E. L. \& R. M. Ryan. 2008. Hedonia, eudaimonia, and wellbeing: An introduction. J. Happiness Stud. 9:1-11. https:// doi.org/10.1007/s10902-006-9018-1

Dedehouanou, S. F. A., J. Swinnen, \& M. Maertens. 2013. Does contracting make farmers happy? Evidence from Senegal. Rev.Income Wealth, 59:138-160. https://doi.org/10.1111/ roiw.12041

Dodge, R., A. P. Daly, J. Huyton, \& L. D. Sanders. 2012. The challenge of defining wellbeing. Int. J. Wellbeing. 2:222235. https://doi.org/10.5502/ijw.v2i3.4

Forgeard, M. J. C., E. Jayawickreme, M. L. Kern, \& M. E. P. Seligman. 2011. Doing the right thing: Measuring wellbeing for public policy. Int. J. Wellbeing. 1:79-106. https://doi. org/10.5502/ijw.v1i1.15

Harianto, N. Kusnadi, \& D. A. Paramita. 2019. The impact of vertical integration intensity on broiler farms technical efficiency: The case of contract farming in West Sumatera. Trop. Anim. Sci. J. 42:167-174. https://doi.org/10.5398/ tasj.2019.42.2.167

Huppert, F. A. 2009. Psychological Well-being: Evidence Regarding its Causes and Consequences. Appl. Psychol. Heal. Well-Being. 1:137-164. https://doi. org/10.1111/j.1758-0854.2009.01008.x

Ilham, N. \& Saptana. 2019. Fluctuations in the chicken egg price and its determining factors. Anal. Kebijak. Pertan. 17:2738. http://dx.doi.org/10.21082/akp.v17n1

Ilham, N. \& Y. Yusdja. 2010. The impact of AI on poultry production and the contribution of poultry business on smallscale farmer's income in Indonesia. J. Agro Ekon. 28:39-68. http://dx.doi.org/10.21082/jae.v28n1.2010.39-68

Kamaruddin, R., J. Ali, \& N. M. Saad. 2013. Happiness and its influencing factors among paddy farmers in Granary Area of Mada. World Appl. Sci. J. 28:91-99.

Khaleeli, H. 2012. Are Farmers Really the Happiest Workers in Britain? The Guardian. https:// www.theguardian.com/uk/shortcuts/2012/jul/23/ are-farmers-really-the-happiest-people

Kurniati, S. A. 2014. Business profile and economic position of broiler Farming in Kuantan Singingi district, Riau province. J. Peternak. Indones. 16:170-178. https://doi. org/10.25077/jpi.16.3.170-178.2014

Kurniawan, H., B. Guntoro, \& Wihandoyo. 2011. Development strategy of layer in Samarinda city East Kalimantan. Bul. Peternak. 35:57-63. https://doi.org/10.21059/buletinpeternak.v35i1.591

Kurniawan, M. F. T., D. P. Darmawan, \& N. W. S. Astiti. 2013. The development strategy of agribusiness layer poultry in Tabanan regency. J. Manaj. Agribisnis. 1:53-66.

Lam, W. W. T., R. Fielding, I. McDowell, J. Johnston, S. Chan, G. M. Leung, \& T. H. Lam. 2012. Perspectives on family health, happiness and harmony $(3 \mathrm{H})$ among Hong Kong Chinese people: a qualitative study. Health Educ. Res. 27:767-79. https://doi.org/10.1093/her/cys087

Latuconsina, Z. M. Y. 2017. Analysis on factors that influence the human development index of Malang regency based on regional approach and panel regression. J. Reg. Rural Dev. Plan. 1:202-216. https://doi.org/10.29244/ jp2wd.2017.1.2.202-216

Lelkes, O. 2006. Tasting freedom: Happiness, religion and economic transition. J. Econ. Behav. Organ. 59:173-194. https://doi.org/10.1016/j.jebo.2004.03.016

Listiani, R., A. Setiyadi, \& S. I. Santoso. 2019. Income analysis of rice production in Mlonggo district, Jepara regency. Agrisocionomics: J. Sos. Ekon. Kebijak. Pertan. 3:50-58. https://doi.org/10.14710/agrisocionomics.v3i1.4018

Mallu, M. H., D. H. Darwanto, S. Hartono, \& J. H. Mulyo. 2018. The competitiveness of beef cattle breeding business on community livestock-based in North Penajam Paser regency, East Kalimantan. Int. J. Econ. Manag. Sci. 7: 501-504. https://doi.org/10.4172/2162-6359.1000548

Mandal, M. K., N. Khandekar, \& P. Khandekar. 2006. Backyard poultry farming in Bareilly district of Uttar Pradesh, India: An analysis. Lives. Res. Rural Dev. 18(7). http://www.lrrd. org/lrrd18/7/mand18101.htm

Maoba, S. 2016. Production performance and profitability analysis of small scale layer projects supported through CASP in Germiston region, Gauteng province. South Africa J. Agric. Extention. 44:42-49. http://dx.doi. org/10.17159/2413-3221/2016/v44n1a368

Martindah, E., N. Ilham, \& E. Basuno. 2014. Biosecurity level of poultry production cluster (PPC) in West Java, Indonesia. Int. J. Poult. Sci. 13:408-415. https://doi.org/10.3923/ ijps.2014.408.415

Mbuza, F., R. Habimana, T. Simbankabo, \& D. Majyambere. 2016. Characterization of layer poultry production in 
Rwanda. Int. J. Agric. Sci. 6:1148-1156.

McNair, W. E., D. M. Lambert, \& N. S. Eash. 2015. Conservation agriculture and household well-being : A non-causal comparison among smallholder farmers in Mozambique. J. Agric. Sci. 7:1-18. https://doi.org/10.5539/jas.v7n1p1

Modiri, F. 2019. A comparison of the shared activities with the spouse between men and women: Similarities and differences. Asia-Pacific Soc. Sci. Rev. 19:175-188.

Msuta, P. B. \& J. K. Urassa. 2015. The contribution of farmers' organizations to smallholder farmers' well-being: A case study of Kasulu district, Tanzania. Afr. J. Agric. Res. 10:2343-2349. https://doi.org/10.5897/AJAR2014.9261

Ngantung, I. F., A. Makalew, V. V. J. Panelewen, \& I. D. R. Lumenta . 2019. Analysis of the rentability laying chicken husbandry business farm UD. Tetey Permai in Dimembe district of Minahasa Utara regency. Zootec. 39:13-22. https://doi.org/10.35792/zot.39.1.2019.21989

Nuryati, Y. \& Y. H. Nur. 2012. The variability of price of ras chicken eggs in Indonesia. Bul. Ilm. Litbang Perdagangan, 6: 235-252.

Odunlami, H. O., P. A. Okuneye, A. M. Shittu, A. R. Sanusi, I. O. Elegbede, \& F. Kies. 2016. Assessment of gender differentials in economic and technical efficiency of poultry egg, a case study in Lagos State, Nigeria. Sustain. Agri. Food Environ. Res. 4:50-60. http://dx.doi.org/10.7770/ safer-V4N1-art977

OECD (Organisation for Economic Co-operation and Development). 2013. OECD Guidelines on Measuring Subjective Well-being. OECD Publishing. https://doi. org/10.1787/9789264191655-en

Ofuoku, A.U. 2012. Influence of extension agents' and farmers' communications factors on the effectiveness poultry technology messages. Trop. Agric. Res. Ext. 15:14-23. http:// dx.doi.org/10.4038/tare.v15i1.5238

Pambudy, R. 2018. The development of adopting innovation on entrepreneurship status of Madura cattle farmers. Trop. Anim. Sci. J. 41:147-156. https://doi.org/10.5398/ tasj.2018.41.2.147

Pelafu, F., M. Najoan, \& F. H. Elly. 2018. The development potential of layer poultry in West Halmahera regency. J. Zootek. 38:209-219. https://doi.org/10.35792/zot.38.1.2018.18941

Permana, T. S. \& M. Q. Fauzy. 2016. The role of urban farming in the welfare of the Muslim farmers in four farmer groups in Surabaya from the perspective of Islam. J. Ekon. Syariah Teor. Terap. 3:945-959.

Primasari, D. \& H. Puspitawati. 2016. Child vulnerability and well-being among farmer families. J. Fam. Sci. 1:25-43. https://doi.org/10.5861/ijrsp.2012.v1i2.80

Rachmat, M. 2013. Farmers' terms of trade: The concept, estimation, and relevance for farmers' welfare indicators. Forum Penelit. Agro Ekon. 31:111-122. https://doi.org/10.21082/ fae.v31n2.2013.111-122

Rahayu, T. P. 2016. The determinants of happiness in Indonesia. J. Ekon. Bisnis. 19:149-170. https://doi.org/10.24914/jeb. v19i1.485

Rahmawati, I. R., M. Muksin, \& R. Rizal. 2016. The role and performance of agriculture extension agent in empowering laying chicken breeders in Jember, East Java Province. J. Penyuluhan. 12:183-189. https://doi.org/10.25015/penyuluhan.v12i2.12252
Reis, H. T. \& S. L. Gable. 2003. Toward a Positive Psychology of Relationships. In C. L. M. Keyes \& J. Haidt (Eds.), Flourishing: Positive psychology and the life well-lived. American Psychological Association. pp. 129-159. https:// doi.org/10.1037/10594-000

Rudatin, A. 2016. Analysis on Indonesia's beef import. Econ. J. Emerg. Mark. 8:65-72. https://doi.org/10.20885/ejem.vol8. iss1.art5

Sari, D. P. \& H. Puspitawati. 2017. Family conflict and harmony of farmers family. J. Fam. Sci. 2:28-41.

Shields, M. A. \& S. W. Price. 2005. Exploring the economic and social determinants of psychological well-being and perceived social support in England. J. R. Stat. Soc. 168:513537. https://doi.org/10.1111/j.1467-985X.2005.00361.x

Smith, S. B., T. Gotoh, \& P. L. Greenwood. 2018. Current situation and future prospects for global beef production: Overview of special Issue. Asian-Australas. J. Anim. Sci. 31:927-932. https://doi.org/10.5713/ajas.18.0405

Statistics Indonesia. 2017. Indeks Kebahagiaan Indonesia Tahun 2017: Vol. 79/08/Th.X. https://www.bps.go.id/pressrelease/2017/08/15/1312/indeks-kebahagiaan-indonesia-tahun-2017-sebesar-70-69-pada-skala-0-100.html [20 August 2019].

Stock, P.V. \& J. Forney. 2014. Farmer autonomy and the farming self. J. Rural Stud. 36:160-171. https://doi.org/10.1016/j. jrurstud.2014.07.004

Suksod, P., M. Dangsuwan, \& K. Jermsittiparsert. 2019. A positive intervention of farmer's psychological capital to improve perceived farming performance: Role of agricultural extension knowledge. Int. J. Innov. Creativity Change. 7:87-106.

Suryani, A. S. 2018. Effect of environmental quality to fulfillment of basic needs in Banten province. Aspirasi: J. Masal. Sos. 9:34-62. https://doi.org/10.22212/aspirasi.v7i1.1084

Tolentino, M. N. \& A. R. Dullas. 2015. Subjective well-being of Filipino farm children. Int. J. Res. Stud. Psychol. 4:47-60. https://doi.org/10.5861/ijrsp.2015.1265

Ulfa, Z., W. Sarengat, \& S. I. Santoso. 2014. Financial analysis of layer at UD. Balebat in Karang Kobar village Sukorejo district Kendal regency. Anim. Agric. J. 3:476-482.

Veenhoven, R. 2012. Cross-national differences in happiness: Cultural measurement bias or effect of culture? Int. J. Wellbeing. 2:333-353. https://doi.org/10.5502/ijw.v2.i4.4

Wibisono, G. M. A. \& Darwanto. 2016. Strategy of strengthening social capital of farmer group in agricultural development. Jejak: J. Econ. Policy. 9:62-81.

Widiati, R., S. Nurtini, S. P. Syahlani, \& B. Aryadi. 2017. Investment analysis for small scale layer chicken business. Bull. Anim. Sci. 41:495-504. https://doi.org/10.21059/buletinpeternak.v41i4.25965

Windon, S. R., S. D. Jepsen, \& S. D. Scheer. 2014. Identifying the factors affecting ohio farmers quality of life quality of life application to farmers. J. NACAA. 7:1-12.

Yakubu, A. \& R. Aidoo. 2015. The determinants of subjective well-being among subsistence farmers in the Northern region of Ghana. J. Agric. Econ. Dev. 4:14-20.

Zaheer, Z. 2015. An updated review on chicken eggs: Production, consumption, management aspects and nutritional benefits to human health. Food Nutri. Sci. 6:1208-1220. https:// doi.org/10.4236/fns.2015.613127 